\title{
Which parameters may influence the duration of hospitalization after vaginal hysterectomy?
}

\author{
Vajinal histerektomi sonrası hangi parametreler hastanede kalım süresini etkiler? \\ Abdulkadir Turgut, Hatice Ender Soydinç, Mehmet Sıddık Evsen, Serdar Başaranoğlu, Ahmet Yalınkaya \\ Department of Obstetrics and Gynaecology, School of Medicine, Dicle University, Diyarbakir, Turkey
}

\section{Abstract}

Objective: To estimate the variables that may affect the duration of hospitalization after vaginal hysterectomy.

Material and Methods: An 11-year retrospective analysis was performed on data derived from 197 patients who underwent vaginal hysterectomy due to non-malignant pathology at a tertiary care center between January 2000 to November 2011.

Results: The average age of the patients in our series was $60.9 \pm 11.1$ with a duration of hospitalization of $11.6 \pm 6.1$ days after vaginal hysterectomy. The grouping variables consisted of age, number of pregnancies, abortions, parities and the presence of intra or postoperative complications. Advanced age ( $>60)$, increased number of pregnancies $(>5)$ and parities $(>5)$ and occurrence of intra or postoperative complications were found to be correlated with the duration of hospitalization after vaginal hysterectomy. Categorical variables were analyzed by Pearson's chi square or the Fisher exact test. The Mann Whitney U test was used to compare groups, while the correlation of variables was assessed with the Spearman Correlation Analysis.

Conclusion: Vaginal hysterectomy is a safe and effective procedure. Advanced age, increased number of pregnancies and parities and occurrence of intra or postoperative complications may prolong the duration of hospitalization after surgery. Increased experience, careful surgical technique and adherence to aseptic principles may improve the cost-effectivity and decrease the duration of hospitalization.

(J Turkish-German Gynecol Assoc 2013; 14: 15-8)

Key words: Pelvic prolapse, treatment, surgery, vaginal hysterectomy, duration of hospitalization

Received: 15 October, 2012

Accepted: 8 February, 2013

\section{Özet}

Amaç: Vajinal histerektomi sonrası hastanede kalım süresini etkileyebilecek değişkenleri değerlendirmek.

Gereç ve Yöntemler: Bu 11 ylllık retrospektif çalışma Ocak 2000 ile Kasım 2011 yılları arasında tersiyer bir merkezde malign olmayan nedenlerle vajinal histerektomi gerçekleştirilmiş 197 hastanın bilgileri kullanılarak yapıldı.

Bulgular: Hastalarımızın ortalama yaşı $60.9 \pm 11.1$ yıl ve vajinal histerektomi sonrası hastanede kalım süresi $11.6 \pm 6.1$ gündü. Gruplandırmadaki değişkenlerimiz yaş, gebelik sayısı, abort sayısı, doğum sayısı ve operasyon sırası veya sonrasında ortaya çıkan komplikasyonları içermekteydi. İleri yaş ( $>60)$, artmış gebelik $(>5)$ ve doğum $(>5)$ sayısı, operasyon sırası veya sonrasında ortaya çıkan komplikasyonların vajinal histerektomi sonrası hastanede kalım süresi ile ilişkili olduğu bulundu. Kategorik değişkenler Pearson Ki Kare testi veya Fisher exact testi ile analiz edildi. Grupların karşılaştırılmasında Mann Whitney U testi, değişkenlerin korelasyonunda Spearman korelasyon analizi kullanıldı.

Sonuçlar: Vajinal histerektomi güvenilir ve etkili bir yöntemdir. İleri yaş, gebelik sayısı ve doğum sayısının fazla olması, operasyon esnasında ve sonrasında ortaya çıkan komplikasyonlar cerrahi sonrası hastanede kalım süresini uzatabilir. Artmış cerrahi deneyim, özenli bir cerrahi teknik ve asepsi kurallarına uymak fiyat-etkinliği arttırabilir ve hastanede kalım süresini azaltabilir.

(J Turkish-German Gynecol Assoc 2013; 14: 15-8)

Anahtar kelimeler: Pelvik prolapsus, tedavi, cerrahi, vajinal histerektomi, hastanede kalım süresi

Geliş Tarihi: 15 Ekim 2012

Kabul Tarihi: 08 Şubat 2013

\section{Introduction}

Hysterectomy may be performed through vaginal, abdominal or laparoscopic routes. Traditionally, vaginal hysterectomy $(\mathrm{VH})$ is offered to women with symptomatic genital prolapse. It not only offers a lower complication rate, but also allows the repair of pelvic prolapse $(1,2)$. Reported benefits of vaginal hysterectomy compared to abdominal hysterectomy include shorter duration of hospital stay, more rapid return to normal daily activities, and fewer unspecified infections or febrile episodes (2). However, it is not still as popular as expected; possibly due to the relative lack of experience and shortage of technical facilities. Increased familiarity with outcomes of $\mathrm{VH}$ may help to eliminate this limitation (3).

The economic aspect of medical services cannot be ignored in the changing circumstances of the world. Duration of hospitalization constitutes an important component of costeffectivity, which gains importance in provision of healthcare services. As far as we know, no published studies have investigated factors affecting the duration of hospitalization after $\mathrm{VH}$ in the literature.

Our aim was to outline parameters that may affect the duration of hospitalization after vaginal hysterectomy in our institution. 


\section{Material and Methods}

Medical records of 197 patients treated surgically with $\mathrm{VH}$ for benign gynecological diseases in the obstetrics and gynecology department of a tertiary care center between January 2000 to November 2011 were studied retrospectively. Approval of the local Institutional Review Board had been obtained. The indication for hysterectomy was based on the criteria proposed by Dicker et al. (4).

The demographics, occurrence of intra and postoperative complications and duration of hospitalization after surgery were noted. Patients were classified into three groups with regard to duration of hospital stay after surgery: Groups 1, 2 and 3 consisted of hospitalization for 0-10 days; $11-20$ days and $>20$ days, respectively. Descriptive data and grouping variables such as age, number of pregnancies, parities, history of abortions and occurence of intra and postoperative complications are shown in Table 1 and Table 2.

The complications were classified according to Dicker's criteria (4): These criteria include febrile morbidity (oral temperature $>38^{\circ} \mathrm{C}$ measured at least 4 hours apart on any 2 postoperative days excluding the first 24 hours after the operation), hemorrhage requiring operative or postoperative blood transfusion, unintended major surgical procedures (laparotomy, repair of a perforated viscous, or unplanned repair of a major blood vessel

Table 1. Descriptive data of our series

\begin{tabular}{|l|c|c|}
\hline & average \pm SD & Range \\
\hline Age & $60.9 \pm 11.1$ & $35-81$ \\
\hline No. of pregnancies & $6.8 \pm 2.2$ & $0-14$ \\
\hline No. of parities & $7.1 \pm 3.0$ & $0-13$ \\
\hline No. of abortions & $0.72 \pm 1.0$ & $0-5$ \\
\hline $\begin{array}{l}\text { Duration of hospitalization } \\
\text { after VH (days) }\end{array}$ & $11.6 \pm 6.1$ & $4-41$ \\
\hline \multicolumn{2}{|l|}{ SD: standard deviation, VH: vaginal hysterectomy } \\
\hline
\end{tabular}

Table 2. Distribution of variables

\begin{tabular}{|l|c|c|c|}
\hline Variable & & $\mathbf{n}$ & $\mathbf{\%}$ \\
\hline \multirow{3}{*}{ Age } & $\leq 60$ & 78 & 39.6 \\
\cline { 2 - 4 } & $>60$ & 119 & 60.4 \\
\hline \multirow{4}{*}{ Number of pregnancies } & $0-5$ & 52 & 26.4 \\
\cline { 2 - 4 } & $6-10$ & 108 & 54.8 \\
\cline { 2 - 4 } & $>10$ & 37 & 18.8 \\
\hline Number of parities & $0-5$ & 72 & 36.5 \\
\cline { 2 - 4 } & $6-10$ & 103 & 52.3 \\
\cline { 2 - 4 } & $>10$ & 22 & 11.2 \\
\hline \multirow{4}{*}{ History of abortion } & Yes & 79 & 40.1 \\
\cline { 2 - 4 } & No & 118 & 59.9 \\
\hline Intra and postoperative complications & Yes & 21 & 10.7 \\
\cline { 2 - 4 } & No & 176 & 89.3 \\
\hline
\end{tabular}

performed intraoperatively or postoperatively during the same hospitalization due to a problem related to the hysterectomy), life-threatening events such as intraoperative or postoperative cardiac or respiratory arrest, myocardial infarct or embolus or anaphylactic shock), re-hospitalization for a complaint or problem related to the hysterectomy and death or complication leading to death occurring intraoperatively or within 42 postoperative days.

Statistical analysis was performed using the Statistical Package for Social Sciences (SPSS Inc, Chicago, IL, USA) 11.0 software for Windows. Categorical variables were analyzed by Pearson's chi square or Fisher exact test. Mann Whitney U test was used to compare groups. Spearman Correlation Analysis was used to assess the correlation of variables.

\section{Results}

The duration of hospitalization after vaginal hysterectomy for the whole study group was $11.6 \pm 6.1$ (range 4 to 41 ) days and was expressed in Table 1. The duration of hospitalization was $15.6 \pm 7.99$ (range 8 to 41 ) days for the complicated group, and $9.82 \pm 3.97$ (range 4 to 19 ) days for the uncomplicated group. Length of hospital stay was prolonged in our series because of the preoperative hospitalization of the patients for electrocardiography, chest radiography, and routine laboratory screening based on age, gender, and concomitant medical diseases. These procedures usually last for 2-4 days according to the underlying cardiovascular or respiratory diseases.

The distribution of complications according to Dicker's criteria was shown in Table 3. Five patients (23.8\%) developed febrile morbidity, four (19.1\%) operative blood transfusion, two (9.5\%) postoperative blood transfusion, four (19.1\%) unintended major surgical procedures, three (14.3\%) life-threatening cardiac or respiratory events, and three (14.3\%) re-hospitalization.

Table 3. The distribution of complications according to Dicker's criteria

\begin{tabular}{|l|c|}
\hline Complications according to Dicker's criteria & n (\%) \\
\hline Febrile morbidity & $5 / 21(23.8 \%)$ \\
\hline $\begin{array}{l}\text { Hemorrhage requiring operative or } \\
\text { postoperative blood transfusion }\end{array}$ & $6 / 21(28.6 \%)$ \\
\hline $\begin{array}{l}\text { Unintended major surgical procedures } \\
\text { laparotomy, repair of a perforated viscous, } \\
\text { or unplanned repair of a major blood vessel } \\
\text { performed intraoperatively or postoperatively } \\
\text { during the same hospitalization due to } \\
\text { a problem related to the hysterectomy) }\end{array}$ & $4 / 21(19.1 \%)$ \\
\hline $\begin{array}{l}\text { Life-threatening events such as intraoperative } \\
\text { or postoperative cardiac or respiratory arrest, } \\
\text { myocardial infarct or embolus } \\
\text { or anaphylactic shock) }\end{array}$ & $3 / 21(14.3 \%)$ \\
\hline $\begin{array}{l}\text { Re-hospitalization for a complaint } \\
\text { or problem related to the hysterectomy }\end{array}$ & $3 / 21(14.3 \%)$ \\
\hline $\begin{array}{l}\text { Death or complication leading to death } \\
\text { occurring intraoperatively } \\
\text { or within } 42 \text { postoperative days }\end{array}$ & $0 / 21(0 \%)$ \\
\hline
\end{tabular}


Analysis results showed that advanced age was correlated to the duration of postoperative hospitalization ( $r s=0.178$, $\mathrm{p}=0.023$ ). Duration of hospitalization was significantly prolonged in patients with $>5$ previous pregnancies ( $r s=0.225$, $\mathrm{p}=0.001$ ). No further difference was noted between durations of hospitalization of patients with $6-10$ and $>10$ previous pregnancies $(p=0.146)$.

Similar results were obtained for the number of parities. Patients with $>5$ parities were likely to be hospitalized for a longer time after surgery ( $r=0.310, p<0.001$ ). There was no difference between the durations of hospitalization of patients with $6-10$ and $>10$ parities $(\mathrm{p}=0.426)$.

The presence of intra- or postoperative complications were strongly associated with the duration of hospitalization in this series $(p<0.001)$, while a history of abortion seemed not to influence the interval for postoperative hospital stay $(p=0.591)$. Previous surgeries were also not correlated to the duration of postoperative hospitalization ( $r s=0.478, \mathrm{p}=0.267$ ).

\section{Discussion}

Vaginal hysterectomy offers several advantages. In addition to the cosmetic benefit, the operating time is shorter, complications are rare, recovery is faster, and overall treatment costs are reduced $(3,5)$. The advent of laparoscopic hysterectomy has not changed these conclusions and it was concluded that specific guidelines should be established to replace abdominal hysterectomy not by laparoscopic hysterectomy but with vaginal hysterectomy $(6,7)$.

The most common indications for vaginal hysterectomy include stress urinary incontinence and pelvic prolapse. Although $\mathrm{VH}$ is advocated in many candidates for hysterectomy, it is not fully devoid of complications (5). In addition to complications, parameters that may affect the duration of hospitalization after $\mathrm{VH}$ are important for exploring the traps and pitfalls of this procedure.

Management of intraoperative and postoperative complications is important to improve the cost-effectivity of $\mathrm{VH}$. We have included nulliparous patients and those with a history of caesarean section and other pelvic surgery in our study. In our series, febrile morbidity and bladder injury were common complications. Febrile morbidity may be due to infections of the urinary tract or vaginal cuff, pelvic abscess and pneumonia (6). Bladder injury can occur in the presence of adhesions in the vesicovaginal space (7). These adhesions may be attributed to previous caesarean sections. A previous caesarean section history can be associated with higher rates of bladder injury. Bladder injuries can occur more frequently in patients without pelvic prolapse or with first-degree pelvic prolapse than in those with second- or third-degree pelvic prolapse. This can be explained by the difficulty in dissection of the vesicouterine fold $(6,7)$. Maximum caution should be exercised to avoid penetration of the urinary bladder during dissection of the vesicouterine fold. Large uterine size can constitute a mechanical difficulty in vaginal hysterectomy. It may prolong the duration of the operation and increase the rate of complications during surgery $(5,7)$. Therefore, a large uterus can represent a contraindication to vaginal hysterectomy and an indication for abdominal hysterectomy for some gynecological surgeons.

There is no consensus about whether nulliparity, history of pelvic surgery and excessive uterine size are contraindications for vaginal hysterectomy $(3,5-7)$. Vaginal hysterectomy may be technically more difficult in nulliparous than in multiparous women. The vagina is narrower and the uterus is less prolapsed in nulliparous women and the operative duration may therefore be longer (6). According to our results, aging, multiparity and presence of complications were found to prolong the duration of hospitalization. Urinary tract and vaginal infections can be sources of febrile morbidity. Aseptic technique and strict use of prophylactic antibiotics can aid the elimination of infections. Structural changes in the uterus due to aging can prolong the duration of hospitalization and increase the likelihood of complications. Multiparity can result in similar impacts and cause anatomical and physiological alterations. Awareness of potential complications in older and multiparous patients is important in preoperative planning and operative performance of the procedure.

Hospitalization after surgery sometimes can be necessary for management of pain after the procedure. Improvement of pain control methods can reduce the rate of hospitalization and its cost (8). Vaginal hysterectomy is reported to result in lower costs and utilization and more favorable functioning, pain, and activity profiles than either abdominal hysterectomy or laparoscopically assisted vaginal hysterectomy (9).

Our study has several limitations. First, interpretation of retrospective data possesses some restrictions. Second, decisions to perform vaginal hysterectomy were made by individual surgeons. Third, cost-effectiveness cannot be evaluated by duration of hospitalization alone. Other aspects like radiology, laboratory, pharmacy, nursing, and operating room costs cannot be ignored. Further studies involving these dimensions are required to reveal the actual cost-effectivity of $\mathrm{VH}$.

In conclusion, vaginal hysterectomy is an efficient treatment for uterovaginal prolapse with quick recovery and low complication rates. Advanced age, increased numbers of pregnancies and parities and occurrence of intra or postoperative complications may prolong the duration of hospitalization after surgery. Increased experience, careful surgical technique and adherence to aseptic principles may improve the cost-effectivity of this procedure and decrease the duration of hospitalization.

\section{Conflict of interest}

No conflict of interest was declared by the authors.

\section{References}

1. Oscarsson U, Poromaa IS, Nüssler E, Löfgren M. No difference in length of hospital stay between laparoscopic and abdominal supravaginal hysterectomy-a preliminary study. Acta Obstet Gynecol Scand 2006; 85: 682-7. [CrossRef]

2. Engh MA, Otterlind L, Stjerndahl JH, Löfgren M. Hysterectomy and incontinence: a study from the Swedish National Register for Gynecologic Surgery. Acta Obstet Gynecol Scand 2006; 85: 614-8. [CrossRef]

3. Akyol D, Esinler I, Guven S, Salman MC, Ayhan A. Vaginal hysterectomy: Results and complications of 886 patients. J Obstet Gynaecol 2006; 26: 777-81. [CrossRef] 
4. Dicker RC, Greenspan JR, Strauss LT, Cowart MR, Scally MJ, Peterson HB, et al. 1982. Complications of abdominal and vaginal hysterectomy among women of reproductive age in the United States. The Collaborative Review of Sterilization. Am J Obstet Gynecol 1982; 144: 841-8.

5. Rafii A, Samain E, Levardon M, Darai E, Deval B. Vaginal hysterectomy for benign disorders in obese women: a prospective study. BJOG 2005; 111: 223-7. [CrossRef]

6. Pakbaz M, Mogren I, Löfgren M. Outcomes of vaginal hysterectomy for uterovaginal prolapse: a population-based, retrospective, cross-sectional study of patient perceptions of results including sexual activity, urinary symptoms, and provided care. BMC Women's Health 2009; 9: 9. [CrossRef]
7. Miskry T, Magos A. Randomized, prospective, double-blind comparison of abdominal and vaginal hysterectomy in women without uterovaginal prolapse. Acta Obstet Gynecol Scand 2003; 82: 351-8. [CrossRef]

8. Al-Fozan H, Dufort J, Kaplow M, Valenti D, Tulandi T. Cost analysis of myomectomy, hysterectomy, and uterine artery embolization. Am J Obstet Gynecol 2002; 187: 1401-4. [CrossRef]

9. Van Den Eeden SK, Glasser M, Mathias SD, Colwell HH, Pasta DJ, Kunz K. Quality of life, health care utilization, and costs among women undergoing hysterectomy in a managed-care setting. Am J Obstet Gynecol 1998; 178: 91-100. [CrossRef] 